\title{
Studi Langgam Desain sebagai Dasar Mendesain Hotel
}

\author{
Nanik Rachmaniyah ${ }^{1}$, Lea K. Anggraeni ${ }^{2}$, Chyntia Putri Adiwijaya ${ }^{3}$ \\ ${ }^{1,2}$ Dosen, ${ }^{3}$ MahasiswaJurusan Desain Interior, ITS, Surabaya 60111, Indonesia \\ ${ }^{1}$ rachmaniyah@gmail.com, ${ }^{2}$ leaanggraeni@yahoo.com, ${ }^{3}$ elchyntia@gmail.com
}

\begin{abstract}
ABSTRAK
Pembangunan Kota Surabaya berdampak pada peningkatan berbagai sektor termasuk ekonomi dan pariwisata. Usaha perhotelan berkembang pesat sejak tahun 2013. Persaingan bisnis perhotelan meningkat. Masing-masing hotel perlu usaha yang lebih keras untuk menarik konsumen. Hotel tidak lagi hanya memperhatikan segi pelayanan dan suasana yang nyaman saja, tetapi juga perlu menghadirkan suasana dengan gaya/langgam tertentu yang berbeda dengan yang lain, terutama pada interiornya. Demi menciptakan suasana tersebut, maka diperlukan suatu pendalaman terhadap karakter langgam desain yang ingin diterapkan serta cara-cara yang tepat untuk mewujudkan langgam tersebut di dalam ruang.

Objek desain yang menjadi bahan penelitian ini adalah sebuah hotel bisnis di sekitar Tugu Bambu Runcing di Kota Surabaya yang berdiri sejak tahun 1975. Hingga saat ini hotel ini baru mengalami satu kali renovasi. Ini tentu sangat berdampak pada kualitas desain interiornya. Tuntutan dalam pemenuhan perkembangan desain ini menjadi penting apabila hotel ingin bersaing dengan hotel-hotel sekelas lainnya.

Penelitiandilakukan untuk mengetahui langgam desain manakah yang paling sesuai untuk diterapkan pada interior hotel bisnis yang sudah berdiri cukup lama. Penelitian dilakukan dengan menyebarkan kuisioner kepada 25 orang pengunjung hotel. Melalui kuisioner ini, dapat diketahui bahwa pengunjung menginginkan adanya renovasi pada objek desain. Hasil penelitian menyimpulkan bahwa langgam desain yang diinginkan mayoritas pengunjung hotel adalah langgam modern klasik dengan sentuhan Jawa. Dalam menerapkan langgam desain ini, kesatuan elemen-elemen desain menjadi aspek penting dalam penentuan berhasil tidaknya penerapan langgam desain tersebut.
\end{abstract}

Kata kunci: Desain, Hotel, Langgam

\section{ABSTRACT}

Surabaya city development has impact on the increase in the development of various sectors including economy and tourism. Hotel business has grown rapidly since 2013. The competition in hospitality business increase, so that each hotel needs more effort to attract customers. The hotel is no longer just paying attention to terms of service and comfortable atmosphere, but also need to bring the atmosphere of certain design style that different from the others, especially in the interior. In order to create such atmosphere, a deepening character of design style need to be applied as well as the proper ways to achieve these design styles in space.

Objects design of the study is an bussines hotel near "Bambu Runcing" monument in Surabaya, which has stood since 1975. Up unil now, the hotel has only been renovated once. This would greatly impact on the quality of its interior design. The fullfilment demands of the development on its design becomes important when the hotel want to compete with others in its class.

The purpose of the study is to determine the most suitable design style to be applied on the interior of the bussines hotel in Surabaya. The study was conducted by distributing questionnaires to 25 visitors. Through this questionnaire, it is known that visitors want a renovation on the objects' design. The study concluded that the desired style of the majority of hotel visitors is modern classic with a touch of Java style. To apply this design style, unity of design elements becomes an important aspect in determining the success or failure in the implementation of the design style.

Keywords : Design, Hotel, Style 


\section{PENDAHULUAN}

Pembangunan Kota Surabaya berdampak peningkatan pada beberapa sektor antara lain: sektor ekonomi, sosial budaya, dan pariwisata. Ini ditandai dengan terus bertumbuhnya bangunan komersial di Surabaya seperti: hotel, pertokoan, mall, restoran dan café. Pertumbuhan bangunan-bangunan komersial tersebut bisa meningkatkan sumber pendapatanekonomi daerah, membuka lapangan kerja baru, serta mengundang wisatawan domestik maupun wisatawan mancanegara. Keberhasilan suatu bangunan komersial ditentukan oleh beberapa faktor antara lain: ketepatan pemilihan lokasi, perancangan elemenelemen eksterior dan suasana interiornya, serta tema yang dipilih untuk merepresentasikan fasilitas komersial tersebut. Hal-hal tersebut harus saling mendukung untuk menciptakan suatu kesatuan yang selaras dengan lingkungan dan nyaman bagi penggunanya.

Bangunan komersial yang akan dipilih sebagai studi kasus di sini adalah hotel, dengan beberapa alasan sebagai berikut, pertama, fenomena pertumbuhan hotel yang cukup pesat di Surabaya. Dalam tahun 2013 hingga 2014, jumlah hotel di Surabaya telah bertambah sebanyak 16 buah dengan total 2.185 kamar (Kompas, 26 Agustus 2014). Kedua, pertumbuhan fasilitas hotel yang cukup pesat menumbuhkan persaingan bisnis yang ketat, yang menyebabkan masing-masing hotel perlu melakukan berbagai upaya untuk menarik perhatian konsumennya. Ketiga, langkah-langkah yang dilakukan hotel untuk menarik konsumen dilakukan antara lain dengan membuat ciri yang berbeda dengan hotel yang lain. Hotel tidak lagi hanya memperhatikan segi pelayanannya, tetapi juga dengan cara menghadirkan suasana yang nyaman dan mempunyai gaya tertentu yang unik dan berbeda dengan hotel lainnya.

Fungsi hotel sebagai bangunan komersial sangat terkait dengan tiga aspek yaitu: aspek penjual, aspek pembeli dan aspek produk yang diperjualbelikan (jasa penginapan). Yang terjadi saat ini, para pengelola hotel mulai memperhatikan aspek di luar tiga aspek tersebut. Dalam usahanya untuk menciptakan dan mendukung fungsi dasar hotel sebagai wadah/ tempat menginap, setiap hotel merencanakan hal-hal yang berkaitan dengan fisik hotel tersebut supaya dapat menjadi tempat yang nyaman dan menyenangkan pengunjungnya. Hal ini diwujudkan melalui elemen-elemen perancangan arsitektur, eksterior dan interiornya. Dari elemen-elemen perancangan itulah akan tercipta suatu kesan secara keseluruhan yang merepresentasikan karakter/ciri hotel seperti yang diinginkan oleh pihak hotel dan bisa diterima pengunjungnya.

Kesan secara keseluruhan terhadap suasana yang diciptakan melalui elemen-elemen perancangan disebut dengan citra. Sedangkan langgam desain adalah bagian dari budaya/ hasil karya manusia yang bisa diartikan sebagai 'style' atau 'gaya' yang terkait dengan suatu ciri (bisa berupa budaya, tokoh, peristiwa sejarah, dan lain-lain). Untuk menghasilkan citra dan langgam yang baik pada sebuah hotel perlu perencanaan yang baik dan 'unity' terhadap elemen-elemen desainnya, pada eksterior dan interiornya.

Saat ini, penerapan langgam dan kesatuan elemen-elemen desain pada interior beberapa hotel belum direncanakan dengan baik, sehingga belum tertangkap kesan dan citra hotel yang unik di mata para pengunjungnya. Elemen-elemen desain yang ada seperti material, bentuk bentukan furnitur, pencahayaan buatan, dan lain sebagainya belum memiliki kesatuan desain yang baik sehingga belum menunjukkan langgam desainnya.

Objek desain yang menjadi bahan penelitian ini adalah sebuah hotel bisnis yang berlokasi dengan dengan monumen Bambu Runcing di Kota Surabaya, telah berdiri sejak tahun 1975 dan baru satu kali mengalami renovasi. Hal ini tentu berdampak terutama pada kelayakan desain interiornya yang berkurang seiring dengan perkembangan waktu. Konsep desain yang 
diterapkan bisa jadi sudah kurang sesuai dengan keinginan masyarakat saat ini. Perkembangan material dan teknologi pun membawa pengaruh besar pada perkembangan desain. Tuntutan dalam pemenuhan perkembangan desain ini menjadi penting apabila sebuah hotel ingin bersaing dengan hotel-hotel sekelas lainnya.

\section{METODOLOGI}

Penelitian ini difokuskan untuk mengetahui apakah penerapan langgam desain yang ada pada eksisting hotel bisnis ini sudah berhasil, serta untuk mengetahui langgam desain manakah yang paling sesuaiuntuk diterapkanpada interiornya. Tiga alternatif langgam desain yang bisa diterapkan pada hotel bisnis ini adalah: Klasik, Modern dan Etnik Jawa. Penelitian dilakukan dengan menyebarkan kuisioner kepada 25 orang pengunjung hotel.

\section{KAJIAN LITERATUR}

\section{A. Karakteristik Langgam Desain}

\section{Langgam Klasik}

Desain Klasik merupakan gambaran sejarah perjalanan arsitektur di Eropa yang secara khusus menunjuk pada karya-karya arsitektur Romawi dan Yunani yang merupakan karyakarya yang bernilai tinggi dan "first class”. Karya-karya ini dibuat dengan aturan danstandar yang ketat dan pertimbangan yang sangat hati-hati sebagai landasan berpikir dalam menciptakan karya tersebut. Karya-karya klasik pada interior merupakan karya-karya yang secara inheren (terkandung dalam benda tersebut yang secara asosiatif seolah-olah selalu melekat dengannya) mengandung nilai-nilai keabadian disamping ketinggian mutu dan nilainya.

Secara umum, ciri dari langgam klasik adalah sebagai berikut [4]:

a. Memiliki banyak sekali ornamen/hiasan pada hampir setiap sudut bangunan/ interior.

b. Penggunaan kolom dan balok (entablature) sebagai elemen utama.

c. Berupa bangunan yang besar dan megah dengan waktu pengerjaan yang cukup lama.

d. Memanfaatkan efek distorsi mata untuk menciptakan kemegahan dan keindahan bangunan-bangunan utamanya.

e. Bahan utama menggunakan bahan yang langsung diambil dari alam.

f. Setiap bagian bangunan pada arsitektur Yunani Kuno adalah bagian integral dari keseluruhan struktur bangunan, sehingga peninggalan bangunan yang tidak sempurna dapat direkonstruksi kembali seperti bangunan asalnya.

\section{Langgam Modern}

Langgam modern diketahui telah berkembang lebih kurang setengah abad, berawal kira kira tahun 1920 hingga 1960, diawali dengan munculnya Revolusi Industri (1760-1863) di Inggris. Revolusi Industri telah membawa perubahan besar dalam bidang teknologi, sosial, dan kebudayaan. Demikian juga dalam bidang arsitektur dan desain yang selalu dipengaruhi oleh perubahan dalam masyarakat. Langgam modern setahap demi setahap menghapuskan ornamen - ornamen dan dekorasi yang banyak terdapat pada era pra-modern dan menggantinya dengan bentuk-bentuk geometris. Bentuk-bentuk geometris yang sederhana menjadi ciri rupa arsitektur langgam modern. 
Pada bulan September 1930 dalam konggres CIAM (Congres Internationaux d'Architecture Moderne) telah didefinisikan : Desain modern adalah pernyataan jiwa dari suatu masa, dapat menyesuaikan diri dengan perubahan sosial dan ekonomi yg ditimbulkan "zaman mesin". Yaitu dengan mencari keharmonisan dari elemen-elemen modern serta mengembalikan desain pada bidangnya (ekonomi, sosiologi, dan kemasyarakatan) yang secara

keseluruhan siap melayani umat manusia. Konsep baru dan sangat mendasar dari langgam modern antara lain adalah FORM FOLLOWS FUNCTION yang dikembangkan oleh Louis Sullivan dari [2]. Setelah berjalan beberapa lama, langgam modern dapat disimpulkan mempunyai ciri sebagai berikut [6] :

a) Terlihat mempunyai keseragaman dalam penggunaan skala manusia.

b) Bangunan bersifat fungsional, artinya sebuah bangunan dapat mencapai tujuan semaksimal mungkin, bila sesuai dengan fungsinya.

c) Bentuk bangunan sederhana dan bersih yang berasal dari seni kubisme dan abstrak yang terdiri dari bentuk-bentuk aneh, tetapi intinya adalah bentuk segi empat.

d) Konstruksi diperlihatkan.

e) Penggunaan bahan pabrik yang ditampakkan secara jujur, tidak diberi ornamen atau tempelan - tempelan dekorasi.

f) Interior dan eksterior bangunan terdiri dari garis-garis vertikal dan horisontal

g) Konsep open plan, yaitu membagi dalam elemen-elemen struktur primer dan sekunder, dengan tujuan untuk mendapatkan fleksibilitas dan variasi di dalam bangunan.

\section{Langgam Etnik Jawa}

Desain langgam etnik berawal dari desain tradisional. Langgam etnik merupakan transformasi desain tradisional dari situasi budaya homogen ke situasi yang lebih heterogen. Dengan situasi yang heterogen langgam etnik berusaha sebisa mungkin menghadirkan citra, bayang-bayang realitas desain tradisional. Penghargaan pada tradisi 'agung' dan 'tinggi' biasanya cukup nyata pada langgam etnik. Citra yang disajikan lebih banyak mengacu pada referensi desain 'rakyat' daripada terhadap bangunan keagamaan, bangunan milik bangsawanpenguasa dan sejenisnya. Referensi pada desain 'rakyat' yang secara fungsional sudah beradaptasi, tepat dan teruji terhadap alam sekitarnya. Desain ini biasanya lebih memiliki kepekaan terhadap lingkungannya secara teknis, sosial, dan kultural.

Langgam etnik merupakan sumber daya setempat yang dibangun dengan teknologi sederhana. Langgam ini dibuat dengan mengakomodasi nilai ekonomi dan tatanan budaya masyarakat setempat. Proses rancang langgam etnik dilandasi oleh pemikiran rasional dan spiritual. Masyarakat menghargai langgam etnik sebagai wujud dari budaya dan kepercayaan masyarakat yang di aplikasikan ke dalam bangunan. Merancang dengan potensi langgam etnik berarti mencari karakteristik desain dari sebuah wilayah.

Penggabungan konsep langgam etnik dengan konsep desain lainnya akan semakin memperkaya konsep desain. Penggabungan ini dapat mewujudkan perkembangan desain sesuai kondisi saat ini tanpa meninggalkan budaya suatu wilayah yang sudah ada sejak lama. Penerapan konsep langgam etnik juga menjadikan desainer lebih menghargai budaya. Untuk bisa menerapkan langgam etnik, desainer dituntut untuk lebih mengetahui dan memahami proses terjadinya budaya pada suatu wilayah yang akan digunakan untuk penerapan konsep langgam etnik.

Keberhasilan penerapan langgam tradisional Jawa terletak pada dua hal penting, yaitu bentuk dan karakteristik visual. Bentuk arsitektur tradisional Jawa dapat dengan mudah dikenali melalui penerapan atap Joglo dan ornamen ukir khas Jawa seperti nanasan, patran, 
tumpal, wajikan dan padma. Ornamen tersebut memberikan ciri khas yang kuat pada interior bangunan Jawa. Identitas ini sudah melekat dan menjadi symbol bentuk tradisional Jawa.

Karakter visual yang sesuai dengan bagunan tradisonal Jawa memiliki perbedaan dengan standarisasi dengan bangunan modern. Pencahayaan bangunan tradisional Jawa cenderung temaram untuk menciptakan kesan berwibawa dan syahdu. Warna yang digunakan cenderung monokromatis atau senada tanpa warna kontras yang terkesan meriah dan ramai. Kesan kedamaian dan ketenangan sangat penting dalam mendukung karakteristik visual di bangunan tradisional Jawa. Hal ini selaras dengan filosofi masyarakat Jawa yang mengedepankan harmoni dan menghindari konflik secara terbuka. Masyarakat Jawa menganggap "aji” atau kewibawaan rumah sebagai salah satu faktor penting dalam penataan interiornya.

Proporsi bangunan tradisonal Jawa juga memiliki karakteristik visual yang khas. Bangunan tradisonal yang dibuat terlalu tinggi ternyata justru menghilangkan kesan megah. Bagian depan sebaiknya tetap dibuat rendah untuk menghindari kesan terbuka yang berlebihan. Proporsi antara tinggi dan lebar bangunan sebaiknya tetap dibuat horisontal agar tercipta kesan lebar dan mewah.

Hal lain yang perlu diperhatikan adalah fungsi ruang dari bangunan tradisonal tersebut. Saat ini fungsi bangunan pendopo telah berubah menjadi berbagai fungsi seperti: lobi hotel, balai desa, restoran atau gedung pernikahan. Yang sulit di bayangkan mungkin merubah pendopo menjadi diskotik dengan lampu redup-gemerlap dan musik yang hingar bingar.

\section{B. Teori Penyampaian Langgam Desain}

\section{Hermeneutika}

Tiga makna hermeneutis yang mendasar yaitu[10] :

a) Mengungkapkan sesuatu yang tadinya masih dalam pikiran melalui kata-kata sebagai medium penyampaian.

b) Menjelaskan secara rasional sesuatu yang masih samar-samar sehingga maknanya dapat dimengerti.

c) Menerjemahkan suatu bahasa yang asing ke dalam bahasa lain.

Tiga pengertian tersebut terangkum dalam pengertian "menafsirkan"- interpreting, understanding. Attew (1984:123) mengatakan bahwa hermeneutik adalah keahlian menginterpretasi karya sastra dan ungkapan bahasa dalam arti yang lebih luas menurut maksudnya. Palmer mendefinisikan hermeneutik sebagai proses mengubah sesuatu atau situasi ketidaktahuan menjadi mengerti [9], sehingga yang menjadi tugas pokok hermeneutik adalah bagaimana menafsirkan sebuah teks klasik menjadi milik kita yang hidup di jaman dan tempat yang berbeda.

Gadamer ingin mencapai kebenaran melalui dialektika [8]. Dialektika adalah proses pemahaman dari hasil peleburan antara horizon-horizon, yakni horizon teks dengan horizon pembaca atau penafsir. Di sini menunjukkan bahwa hermeneutika adalah peristiwa dialektik atau dialektikal (dialog). Selanjutnya Gadamer menyebutkan bahwa ada empat konsep tentang manusia yang memperkaya hermeneutika atau penafsiran dan pemahaman, yaitu bildung atau kebudayaan, sensus communis atau pendapat bersama, pertimbangan praktis yang baik, dan taste atau selera.

\section{Semiotika}

Pierce dengan teori semiotikanya menggagas tiga buah tanda yang dapat digunakan sebagai media bahasa untuk dasar menerapkan atau menyampaikan langgam desain dalam sebuah karya desain interior, dalam hal ini objek studi hotel bisnis di Surabaya. 
Peirce membedakan tiga konsep dasar semiotik, yaitu: sintaksis semiotik, semantik semiotik, dan pragmatik semiotik. Pragmatik semiotik mempelajari hubungan antara tanda, pemakai tanda, dan pemakaian tanda.

Berdasarkan objeknya, Peirce membagi tanda menjadi : icon (ikon), index (indeks), dan symbol (simbol) dengan penjelasan berikut[1]:

a) Ikon adalah tanda yang hubungan antara penanda dan petandanya bersifat bersamaan bentuk alamiah. Dengan kata lain, ikon adalah hubungan antara tanda dan objek atau acuan yang bersifat kemiripan; misalnya foto.

b) Indeks adalah tanda yang menunjukkan adanya hubungan alamiah antara tanda dan petanda yang bersifat kausal atau hubungan sebab akibat, atau tanda yang langsung mengacu pada kenyataan; misalnya asap sebagai tanda adanya api.

c) Simbol adalah tanda yang menunjukkan hubungan alamiah antara penanda dengan petandanya.

Hubungan di antaranya bersifat arbitrer, hubungan berdasarkan konvensi masyarakat. Berdasarkan interpretant, tanda (sign, representamen) dibagi atas 'rheme', “dicent sign” atau 'dicisign' dan 'argument'. 'Rheme' adalah tanda yang memungkinkan orang menafsirkan berdasarkan pilihan. "Dicent sign” atau 'dicisign' adalah tanda sesuai dengan kenyataan. Sedangkan 'argument' adalah yang langsung memberikan alasan tentang sesuatu.

\section{HASIL DAN PEMBAHASAN}

\section{Demografi Responden}

Dengan mengetahui identitas pengunjung, secara tidak langsung informasi mengenai mayoritas pengunjung dan segmentasi pasar hotel dapat diketahui pula. Segmentasi pasar ini menjadi hal yang penting sebagai bahan pertimbangan dalam menentukan kesan dan konsep seperti apa yang hendak diberikan oleh hotel. Mayoritas dari pengunjung hotel bisnis semacam ini merupakan para pekerja kantoran (karyawan) berusia 31-40 tahun (52\%), hal ini sesuai dengan strategi pemasaran hotel yang sering memberi promo-promo diskon kepada perusahaan milik negara (BUMN) untuk menggunakan fasilitas di hotel bisnis ini kepada para karyawannya.

Melihat hasil analisa ini, dapat ditentukan bahwa langgam desain yang akan diangkat harus mampu merepresentasikan karakter pengunjung hotel.

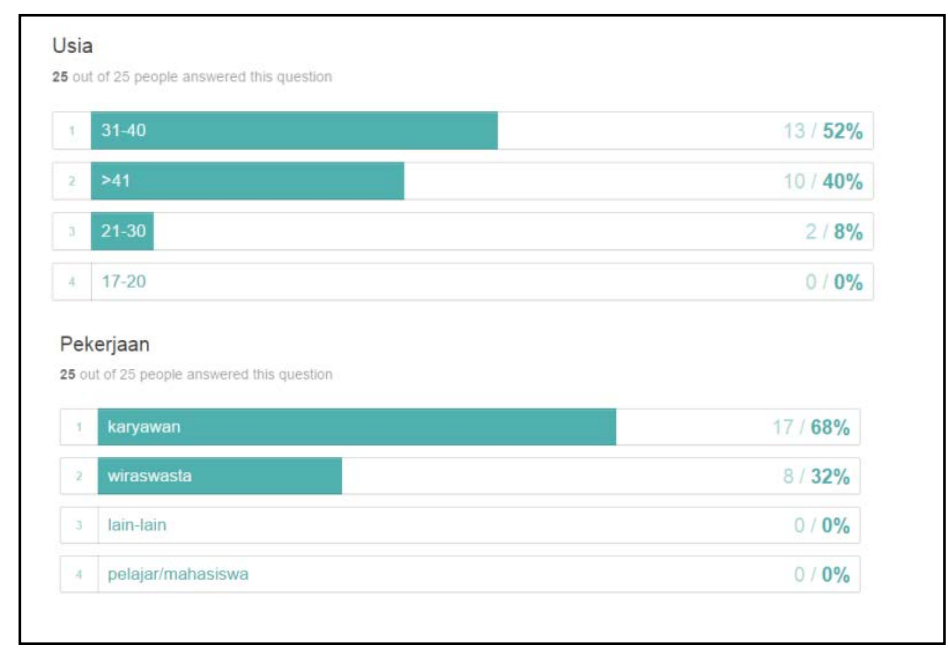

Gambar 1. Persentase Usia dan Pekerjaan Pengunjung. 


\section{Tingkat Kedekatan Pengunjung dengan Objek}

Hasil kuisioner 56\% pengunjung menyatakan bahwa ini merupakan pengalaman pertama mereka menginap di hotel bisnis ini. Hal ini menandakan bahwa pengunjung belum terlalu familier dengan 'nama' hotel sehingga baru pertama kali memilih untuk menginap di hotel ini. Mayoritas pengunjung menyatakan bahwa mereka mengetahui tentang hotel yang menjadi studi kasus ini dari situs internet (44\%) dan tertarik karena harganya yang terjangkau (44\%).

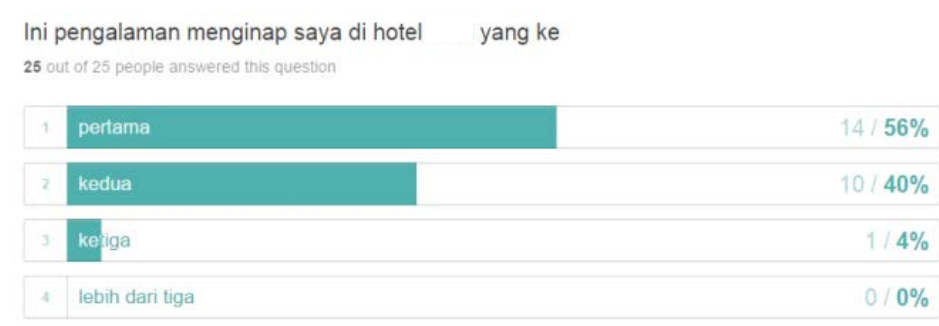

Gambar 2. Persentase Pengalaman Menginap Pengunjung.

Sebagai hotel yang telah berdiri sejak tahun 1975, 'nama' hotel kurang dikenal dan kurang dekat dengan pengunjung sehingga patut disayangkan. Hal yang perlu dijadikan perhatian yakni adanya suatu kebutuhan untuk melakukan redesain hotel dengan konsep langgam yang menarik sehingga hotel mampu bersaing dengan hotel-hotel baru yang banyak bermunculan di Surabaya.

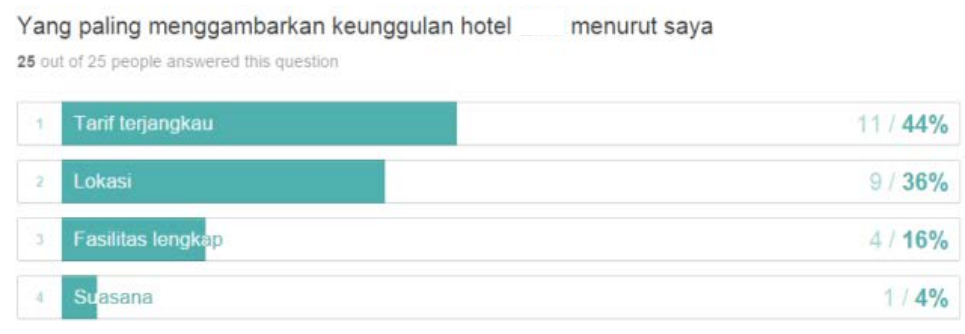

Gambar 3. Persentase Faktor Keunggulan Hotel.

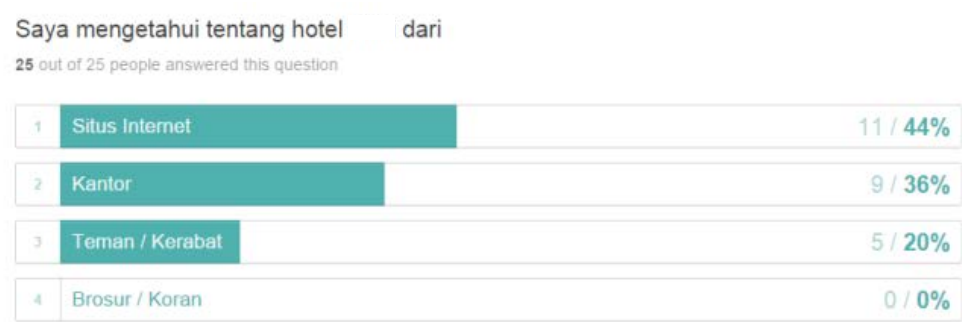

Gambar 4. Persentase Informasi Keberadaan Hotel.

\section{Tingkat Kepuasan Pengunjung}

Tingkat kepuasan pengunjung ketika menginap di sebuah hotel menjadi dasar kepentingan dalam merancang ulang desain hotel. Hasil kuisioner menyatakan bahwa mayoritas pengunjung telah merasa puas dengan pelayanan, sirkulasi dan tata ruang hotel sehingga bersedia untuk merekomendasikan hotel bisnis yang menjadi obyek penelitian ini kepada kerabat mereka (88\%). Dengan demikian disimpulkan bahwa hotel ini telah cukup baik dan mampu memenuhi kebutuhan pengunjung sehingga membuat pengunjung merasa puas. 


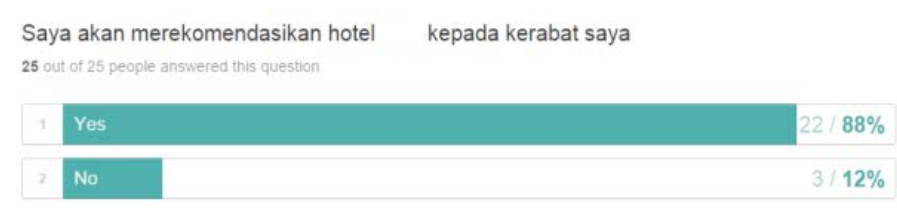

Gambar 5. Persentase Tingkat Kepuasan Pengunjung.

Bila dilihat, pelayanan dan sistem sirkulasi di hotel bisnis yang menjadi obyek penelitian ini telah cukup baik dalam mengakomodasi pengunjungnya. Dapat dikatakan kelemahan yang terdapat pada objek penelitian memang terletak pada belum adanya kesatuan elemen-elemen desain yang mampu membentuk kesan dan citra hotel. Kelemahan ini juga ditambah dengan kondisi beberapa material hotel yang rusak karena dimakan waktu.

Di sinilah dibutuhkan adanya sebuah konsep langgam desain yang sesuai dengan segmentasi pengunjung serta dapat diaplikasikan dengan baik di dalam ruang hotel.

\section{Kebutuhan Pengunjung}

Beberapa hiburan dan kebutuhan pengunjung tentang perasaan aman dan nyaman ketika berada di dalam hotel penting untuk diketahui sebagai dasar dalam merancang. Hasil kuisioner menyatakan bahwa pertunjukan gamelan(52\%) dan live music (60\%) merupakan dua hiburan yang diinginkan oleh sebagian besar pengunjung hotel. Keinginan akan adanya pertunjukan gamelan juga menunjukan bahwa adanya keinginan untuk memasukkan unsur budaya dalam konsep langgam desain.

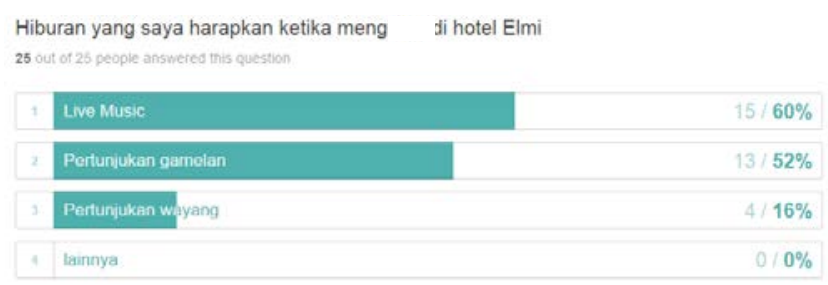

Gambar 6. Persentase Kebutuhan Akan Hiburan di Hotel.

Perasaan aman dan nyaman ketika berada dalam sebuah ruang merupakan kebutuhan esensial dalam suatu desain. Hasil kuisioner menyatakan bahwa adanya keinginan perubahan elemen desain demi mencapai perasaan tersebut. Elemen desain yang dimaksud antara lain furnitur (88\%), material (44\%), dan pencahayaan (36\%).

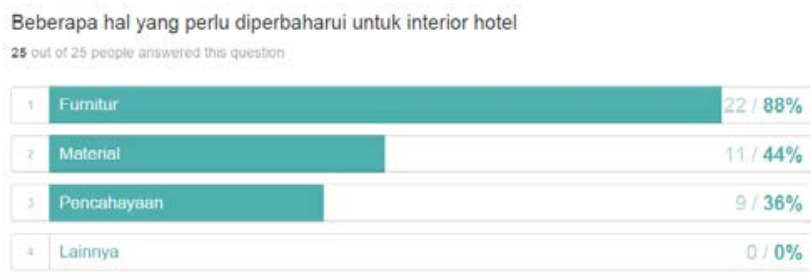

Gambar 7. Persentase Kebutuhan Akan Perubahan di Hotel.

\section{Aktifitas Pengunjung}

Mengetahui aktifitas pengunjung akan membantu dalam menentukan konsep langgam desain. Pengunjung hotel yang menjadi obyek penelitian ini mayoritas menginap untuk melakukan kebutuhan bisnis (56\%), membutuhkan suatu desain yang mampu mendukung aktifitas bisnisnya. Beberapa dari mereka (40\%), melakukan pertemuan dengan rekan bisnis 
di area lobi hotel sehingga desain lobi harus mampu memberi kesan yang baik dan menunjang aktifitas tersebut.

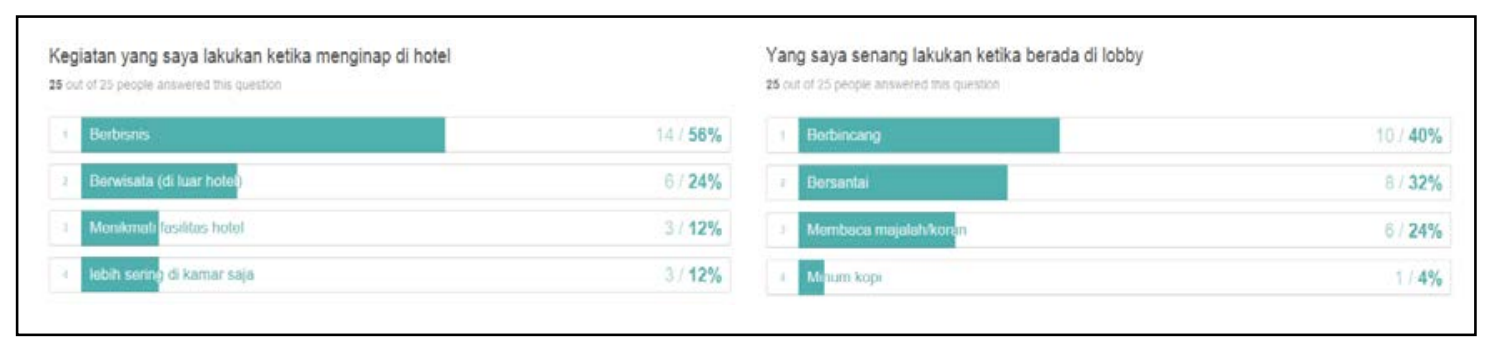

Gambar 8. Persentase Kegiatan Pengunjung.

Selain itu, sekitar 36\% pengunjung menyatakan melakukan aktifitas bekerja/menulis ketika berada di area kamar sehingga pencahayaan yang ada di kamar harus menunjang aktifitas bekerja maupun aktifitas tidur/beristirahat.

\section{Langgam Desain}

Berdasarkan kuisioner yang dilakukan, langgam desain yang paling banyak disukai oleh pengunjung hotel bisnis yang menjadi obyek penelitian ini adalah langgam modern klasik (68\%) yang memberi kesan dan citra hotel yang mewah. Hal ini berkaitan dengan latar belakang pengunjung hotel yang kebanyakan berasal dari kalangan pebisnis dan pekerja kantoran. Disisi lain, langgam etnik Jawa juga disukai pengunjung (36\%) sebagai sentuhan dalam desain.

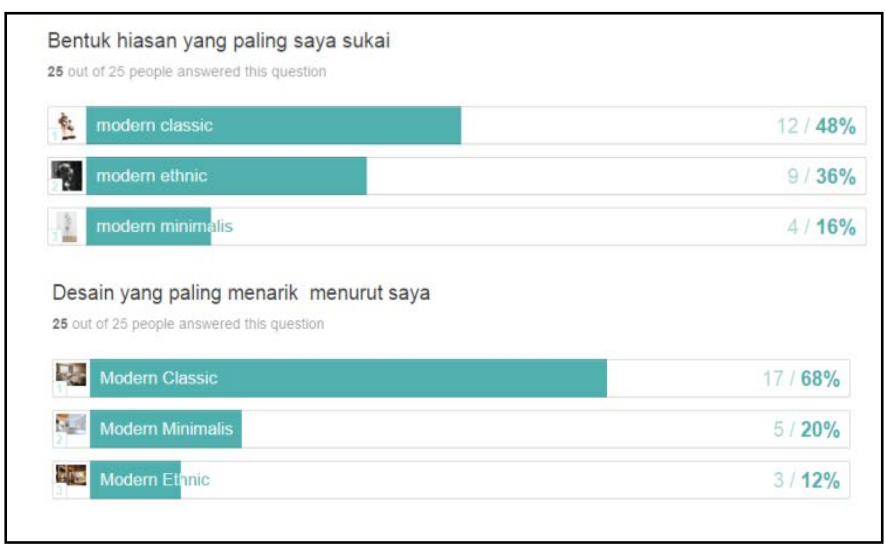

Gambar 9. Persentase Langgam Desain.

Berdasarkan analisa kuisioner tersebut dapat disimpulkan bahwa konsep langgam yang sesuai untuk diterapkan dalam interior hotel bisnis yang menjadi obyek penelitian ini adalah langgam modern klasik dengan sentuhan etnik Jawa.

\section{KESIMPULAN}

Berdasarkan analisa dan pembahasan penelitian mengenai studi langgam desain sebagai dasar merancang hotel di Surabaya, dapat ditarik kesimpulan yaitu:

1. Penerapan langgam desain pada eksisting objek hotel yang menjadi obyek penelitian masih bisa ditingkatkan. Hasil kuisioner menyampaikan bahwa sebagian besar 
pengunjung merasa desain yang ada saat ini belum sesuai dengan keinginan dan kecenderungan kebanyakan pengunjung.

2. Langgam yang sesuai untuk diterapkan di hotel bisnis yang berlokasi di kawasan monumen Bambu Runcing Surabaya adalah langgam modern klasik dengan sentuhan etnik Jawa.

3. Elemen-elemen desain yang mencapai kesatuan yang baik akan mampu menampilkan langgam desain yang dimaksud yakni langgam desain modernklasik dengan sentuhan etnik Jawa.

Penelitian ini juga menghasilkan saran yang sekiranya dapat bermanfaat untuk pihakpihak terkait, antara lain:

1. Melihat masih adanya kekurangan pada eksisting objek hotel yang diteliti, maka perlu diadakan renovasi maupun redesain yang mampu memenuhi kebutuhan fisik dan psikologi pengunjung hotel.

2. Dalam merancang, perlu dilihat adanya kesatuan elemen-elemen desain sehingga tercapai suatu karakteristik langgam yang mampu memberi kesan dan citra yang baik kepada pengunjungnya.

Dalam usaha menciptakan suatu langgam desain yang baik dalam ruang, dapat digunakan teori-teori yang mempermudah penyampaian karakteristik langgam. Teori-teori yang dimaksud antara lain teori hermeneutika yang diusung oleh Gadamer dan teori semiotika yang diusung oleh Peirce.

\section{PUSTAKA}

[1] Istanto, Freddy H. (2000).Rajutan Semiotika untuk Sebuah Iklan; Studi Kasus Iklan Long Beach. Jurnal Nirmana Vol. 2, No. 2, Juli 2000, Indonesia

[2] Anonim.(2008). Arsitektur Modern.Tersedia:https://zenadanx.wordpress.com/2008/ 05/18/arsitektur-modern/

[3] Aji ,BanuWishnu. (2008). Karakteristik Visual Interior Tradisional Jawa. tersedia: https://artbanu.wordpress.com/2008/11/16/karakteristik-visual-interior-tradisional-jawa/

[4] Aulia, Rezqi. (2015). Sejarah Perkembangan Arsitektur Klasik.Tersedia: http://www.academia.edu/12509025/Sejarah_Perkembangan_Arsitektur_Klasik)

[5] Christian, Ign.(2015). Semiotika. Tersedia: https://id.wikipedia.org/wiki/Semiotika

[6] Daeng, (2015). Perkembangan Arsitektur. Tersedia:https://id.scribd.com/doc/269989226/Perkembangan-Arsitektur

[7] Djaelani,Diesty Paramitha.(2014). Langgam Arsitektur. Tersedia: http://diestylands.blogspot.co.id/2012 /04/langgam-arsitektur.html

[8] Inezta, Iroel. (2012).Macam-macam Hermeneutika Beserta Tokohnya. Tersedia: http://ruruls4y.wordpress.com /2012/05/29/macam-macam-hermeneutika-besertatokohnya/

[9] Melani, Aulia.(2011). Pendekatan Hermeneutik.Tersedia: http://ketikaungumerasukkalbu.blogspot.com/ 2011/12/pendekatan-hermeneutik.html

[10] Thoyyar,Husni, Nenk Ai Siti Farida.(2014). Hermeneutika. Tersedia: http://tugasmahasiswa-iaid.blogspot.co.id /2014/11/nenk-ai-siti-farida.html 